\title{
"Pasawari Kunci Negeri" Tracking the Value of Religious Moderation in the Oral Traditions of the Maluku People
}

\author{
Wardiah Hamid ${ }^{1}$, Rismawidiawati ${ }^{2}$, Muh. Subair ${ }^{3}$, Abu Muslim ${ }^{4}$ \\ \{wardiahlitbang@yahoo.co.id ${ }^{1}$, rismawidiawati@gmail.com², ingatbair@gmail.com ${ }^{3}$, \\ abumuslim.litbang@gmail.com $\left.{ }^{4}\right\}$ \\ Balai Litbang Agama, Makassar ${ }^{1,2,3,4}$
}

\begin{abstract}
This study aims to trace the value of religious moderation in oral traditions in Maluku Province. Oral traditions that contain religious moderation have the potential to build a climate of peace. In Maluku, there is much potential for local wisdom, especially oral traditions, which has the potential to establish principles of life balance and social justice. One of them is reflected in Pasawari. Pasawari contains historical, spiritual, moral values and rules of customs, which are ancestral heritage, regulating people to live orderly, live peacefully, and respect each other. Besides, Pasawari also participates in inviting the community to maintain the balance of nature. The peak of the implementation of the Pasawari was later known as the "Pasawari Kunci Negeri," where all the children of the country from different religious and social backgrounds together donated crops to be used as much as possible in the construction of houses of worship, both mosques, and churches. The Oral Tradition Development Strategy as an essential part of further strengthening religious moderation can be designed on a village/country scale and then on a city scale, bearing in mind that priests, imam, teachers, and legendary figures are "tiga batu tungku" that must always work together and complement each other.
\end{abstract}

Keywords: Pasawari, religious moderation, oral traditions, basudara, patalima

\section{Introduction}

This research was carried out in Maluku Province, which is famous for its diverse local wisdom. This local wisdom has the potential to glue among fellow Basudara people in Maluku and other ethnic groups. The history of Maluku, which has been ravaged by conflicts between tribes and religions, is a dark record that continues to haunt and color the joint lines of their lives. The ruins of buildings that burned down can still be seen in various corners of cities and villages in Maluku Province, Ambon City, and surrounding areas. It is still clear that the segregation of settlements between Muslims and Christians naturally formed, but even so, some Muslim residents have begun to enter and settle in Christian-majority areas such as the Lateri area of Ambon City. This indicates that Muslims have begun to try to blend in permanently with their Christian brothers and sisters.

The economy has begun to stretch in this area; economic centers such as Mall Matahari, Informa, Ace Transmart, and others stand majestically in the centers of Ambon city. The centers of the Batu Merah market and the Mardika market are very crowded and become a place where various ethnic groups and different religions and beliefs interact with each other. Likewise, places of worship, such as mosques and churches, stand majestically along the road. 
In the field of education, the leading university in this city, Pattimura University (UNPATTI), has become a separate icon for millennial generations to study. Various new faculties have been opened on campus, one of them is the faculty of medicine, which has become the campus idol. Ambon State Islamic School of Religion began to change its status to become the Ambon State Islamic Institute of Religion and became the largest Islamic Education institution in Maluku City. The Islamic generations made this campus the face of their new civilization to demand the religion of Islam, and various Christian colleges and universities became places of study.

The mention of Negeri is an area at the village level, and the governor is called raja / Upu latu pati. In it, there are traditional instruments, one of which is Saniri, who is in charge of regulating such as the determination of the king from the eyes of the house, issues relating to customs in a country where he is in power. Saniri is the king's apparatus/king's staff, in their government system, such as the head of affairs. Saniri is representative of the eyes of the house, who sits in a government institution. Saniri Negeri for Batu Merah country has a place to work every day in the village government/village office, and they have so many tasks and functions. Serve various problems of the country together with the village head where he works Together to serve the people of the country while Upu latu / king comes from a descendant who has ancestors who indeed came from the king of his descendants and this applies from generation to generation. Furthermore, Opu Latu must come from the male sex, and this is inseparable from the duties assigned to him, such as marrying the bride and groom in a customary manner, becoming an imam, and so on. This applies in Muslim areas only because this task cannot be performed by women. However, in Christian areas, the position of Opu Latu or the king can be raised from women (Interview of the chairman of the Saniri Batu Merah Ambon 07/13/2019).

The term "land" was not originally derived from the native language of this region or "land language"; this name has been coined by the Dutch, according to S.1824-19a Ordinance. A country is a regional alliance consisting of several questions, which generally consist of at least three. Maluku Provincial Regulation Number 14 of 2005 formulates the country as a Customary Law Community Unit that has territorial boundaries, which has the authority to regulate and manage the interests of local communities based on their origin, local customs recognized and respected in the system of Government of the Unitary State of the Republic of Indonesia. Related to Moluccan children or Moluccans, they are species that have a relationship to live with customs, traditions, culture, kinship, and diversity or traditional religious ways of life. The word Maluku has several meanings, one of which is the word Maluku, derived from the term 'jazirah al-muluk' (semenanjung raja-raja) [1, p. 94].

Maluku has various sub-tribes consisting of, Southeast Maluku, Central Maluku, North Maluku, Southwest Maluku, and Southwest Southeast Maluku. They have oral traditions that are largely based on the environment in which they are located. Oral traditions in Maluku always juxtapose nature in its stanzas such as trees, rocks, sea, rivers, and others. Humans always adapt nature to life and the environment, which they understand that nature has a life, so humans observe and try in every move and step always to digest natural phenomena and try to maintain the balance of nature well. Growing plants have lived, and so animals have lives. For example, the sago tree, from the outside point of view of the sago tree, is terrifying; the trunk is thorny and makes me afraid to touch it. Nevertheless, this sago tree has the benefit of stems, leaves, and starch contents in the stems containing starch extract, starch-containing carbohydrates, the branches are split into roofs, roots that are decomposed by nature will produce sago worms that have high protein. From this sago tree, it is all useful. The Moluccan philosophy was born from the sago tree, as seen from the appearance of the black and curly Maluku people. However, his heart is white and soft like a sago tree when it is split, and it will look white inside and soft. The 
softness of the texture of sago flour like that is the character of the Moluccans that is very friendly and kind (Interview of Unpati Lecturer Unpati 7/13/2019).

There are several things to be achieved as an implementation of religious moderation in Indonesia, one of which is the strengthening of tolerance, both social, political, and religious tolerance [2], [3], [4]. Tolerance is an attitude to provide space and not interfere with the rights of others to believe, express their beliefs, express opinions, even though it is different from what we believe [5], [6], [7]. Thus, tolerance refers to openness, grace, voluntary, and tenderness in accepting differences [8], [9], [10]. Another pillar of strengthening religious moderation is the commitment to the nation which recognizes the state constitution as the regulator of national life [11], [12]. The position of the state in giving freedom to practice religion for religious followers must be viewed with a fair attitude, just as freedom of thought which creates internal differences in religious understanding which must also be respected [13], [13]. That Indonesia is a country that recognizes the existence of religions and beliefs that can be adhered to by society [14]. So that someone should not judge followers of other religions on the basis of differences or displeasure. Moderation means non-violence, and is accommodating to traditions and customs that take place in society [15], [16].

Studies on tolerance in Maluku as part of religious moderation have often been carried out, especially in relation to dialogues between religious leaders and figures of warrior files [17]. Dialogue is also seen as an effective means of building tolerance between religious adherents in Maluku [18]. Studies on local wisdom have also been frequently carried out as social capital to build tolerance and melt condical seeds [19]. Such as research on pela wisdom in Ambonese society [20], [21], [22]. However, from various previous studies, there has not been found any studies on Pasawari and its relationship with the development of religious moderation. Knitting religious moderation in Maluku in terms of oral traditions is too diverse. It became the necessary capital to organize Maluku that had been stricken by conflict, to be raised to the surface in reminding the memory between the two basudara that their ancestors had instilled oral traditions laden with the meaning of brotherhood.

In general, Maluku Province has social capital in knitting togetherness in local wisdom and the culture of Pela Gandong, Masohi, and Pasawari. All of them are socio-cultural institutions that can build a good society. This potential demands the totality of mobilizing our ability to revitalize and develop these cultures, to be able to answer the guidance of a society that is constantly changing. In this way, it is hoped that violent conflict can be minimized, and the creation of a Good Society can be realized [23, p. 26].

In Maluku itself, the orientation of the development of local wisdom, which has the potential to build social harmony and is a cultural seed oriented to the call for peace, can be found in a fairly different frame. We can trace the appeal in the articulation and or texts of Kapata, Pantong, and Jugulu-Jugulu. [24]. When these kapata are spoken, they are called palane. Likewise, dances and singing that contain the value of religious understanding are still promoted and exhibited in certain events, one of which is the Lenso dance, which contains the value of the spirit of unity. As well as eating betel nut, this ritual is performed at a marriage ceremony or an agreement between one country and another, or a bond of brotherhood between two brothers with different beliefs or the same beliefs. Likewise, Pasawari conducted by traditional institutions as infrastructure to serve the public.

The philosophy of local wisdom in Maluku, in this case, Orang Basudara, is a basic mental attitude that provides motivational power for the country's children. He directs every community member to fight for peace between people. Local wisdom is acted as a sacred ethos or tradition inherited from generation to generation in order to maintain the dignity and identity of the people of the breasts, both in the family, country, general public, and civilization in 
general (Wathloi, dkk., 2018, p. 109).

This study aims to determine the oral traditions contained in local communities oriented to religious moderation. It is enabling oral tradition in building a climate of religious moderation. Strategies for developing Oral Traditions that contain elements of Religious Moderation are implementing policies.

This type of research is descriptive qualitative, which tries to describe religious moderation in oral traditions in the community. The research technique begins with the interview stage with the informants directly related to the oral tradition speakers, traditional leaders, community leaders, and religious leaders. Field observations were made at several points in the area that still tell oral traditions that contain religious moderation. Likewise, the study documents in the form of literature relating directly and indirectly to religious moderation in the oral tradition.

\section{Results and Discussion}

\section{Oral Traditions Containing Moderation Values}

Adat is the core of Ambonese identity, and they are influential in understanding adat and practicing it. Although Christians and Muslims are very religious, custom always forms the basis of Ambonese philosophy of life and largely determines the prevailing ethos, namely the spirit of its cultural ethos. While on the one hand, adat reinforces traditional social habits and social interactions; on the other hand, customs legitimize themselves through traditional preChristian and pre-Muslim beliefs, which Ambonese now call traditional religion, which is different from Christianity and Islam [26]. One custom that is maintained is pasawari, which is an unwritten habit that regulates social relations. Maluku people are a heterogeneous society, yet they are bound by strong cultural roots that unite them in diversity.

\section{Pasawari}

Pasawari was born from their ancestors who tried to talk through oral traditions with their ancestors, in the language of the land they understood. The older people's habits when expressing their problems, about the security of the country, guarding the gardens, guarding the oceans and problems of life of the country. With the hope that they will always be protected in danger and given a blessing (fortune) and avoided all hostility from fellow humans. Love of respect for nature, plants, fellow humans is teaching that contains in this oral tradition. Whatever social differences, tribes, and religions must always maintain the peace of the country. Excavation of the values of the past that still has significance when revived. As a driver of peace for humankind. Adat has long been proven able to maintain peace for centuries because of the basic principles of Ale Rasa Beta Rasa, Saki in Nails in Sago Salempeng Meat in two eyes, Katong Samua Basudara [27].

Although unilaterally, the modernists consider the ancestral ceremonial traditions can no longer be maintained. A culture is a form of backwardness and underdevelopment of various changes and progress of this community because the community is led to be bound by customary rules so that they are not free to develop. Nevertheless, according to Anthony Giddens (in Ashad Kusuma) globalization and modernity when meeting traditional culture as a two-way process, where both influence and face to face. Giddens emphasized that his view of globalization and modernity raised the local culture. (GOPASA.jspessirero.blogspot.com Social Culture Transformation in Rural Development). 
To live a tradition or to preserve tradition in modern life is not easy because it conflicts with one another. However, the awareness that tradition is something that arises in the process, which has long agreed with the group, has historical, spiritual, moral, artistic, mythical, and local wisdom values and so on. Tradition develops in the processes that are formed by humanhuman interaction with nature and the harmony of human relations with God Almighty [28, p. 70].

There is an acknowledgment that the elements contained in the "Pasawari" ceremonial tradition contain historical, spiritual, moral values, as well as rules of customs and traditions, which are an ancestral inheritance, regulating people to live orderly, live peacefully and respect one another. Furthermore, most importantly, how people maintain the balance of nature. So the "Pasawari" ceremony will always be carried out in order to remind the inhabitants of the country that this custom seeks to awaken the imagination of appreciation for the values of local wisdom that contain acknowledgment to the creator of the universal regulator, that God teaches goodness and humans must always depend on HIM.

Religious teachings have a significant influence in uniting people's life perceptions about all life expectancies. As one direction of social life, the patterning process is more systematic and ingrained. In patterning, religious, social behavior enters the human conscience so that the main reason for searching for a meaning of life is not yet perfect if the substance of religious teachings is not used as the most epistemologically and axiologically essential reference [29, p. 2]. Community social behavior that is forming from culture is then implementing in the form of rituals carried out by the community, continually juxtaposing it with religious teachings. Religious teachings that are supported by the ritual system become a stepping stone to organize people to live in peace amid ethnic, ethnic, and religious pluralism.

Rite/ritual or rite (English) comes from Latin, which is interpreted as a religious procedure or religious ceremony. The ritual is usually done at certain times, repeatedly from time to time. Rituals in everyday society can be divided into two, namely rituals that are proven, and sacred rituals, because religious people generally use the word Rite/ritual, this word is then interpreted as worship. In this perspective, worship (rite/ritual) is part of an active and observable religious behavior, because in the rite/ritual there are utterances (mantras), worship, singing, prayer, dancing, clothing, clothing, symbols and actions specific actions that can be seen, heard, and felt by the human senses [30, p. 95].

Pasawari, almost all countries in Central Maluku, do it. Pasawari is a ritual of worshiping complaints to ancestors about the problems of the land they face. Moreover, when the Samawi religion entered, some of the contents of this oral tradition changed, namely the position, God / Allah (UPU Lanite), was in the first position and the position of the ancestors (ancestors) came in second. The mention of the ancestors is not servitude but a way to commemorate them with all the good they teach the present generation.

Hundreds of years ago, the Moluccan ancestors before Islam and Christianity entered the region, and their beliefs were animism and dynamism. They believe there is a power in nature that creates their lives. They also believe that their ancestors who have died always see and supervise all of the happening. So that the oaths that their ancestors have confirmed cannot be broken, so when it breaks, there will be a disaster that will befall. So, the position of their parents and traditional leaders will always look after and remind their descendants not to violate the rules of the previous ancestors.

Dieter Bartels, who examined Ambon's pattern of religious conversion, borrowed the concept of "semantic depletion" from the German anthropologist, Adilf E Jensen. From it, he saw that traditional religion as a mythical view, changed to a new religion that taught one of the faith, motivating the love of fellow creatures of God and other teachings. This symbolic 
transformation of religion is referred to by Bartels as "Pseudo-motivation" or "pseudo-purposes. Relocation used is to inject between the religion of the ancestors with the religion that came from the Bible. With the pride of church life and Christianity considered as "Ambon religion"[31, p. 37].

Usually, "Pasawari" will always chant the oral tradition as follows:

\begin{tabular}{|l|l|}
\hline $\begin{array}{l}\text { Ami Somba Puu Lanite } \\
\text { Bumi sasorga }\end{array}$ & $\begin{array}{l}\text { We worship the God of the heavens } \\
\text { and earth that is in heaven }\end{array}$ \\
\hline $\begin{array}{l}\text { Sei Hale Hatu, } \\
\text { Hatu Lisa Pei, Sei Lesi Sou, Sou Lesi Ei" }\end{array}$ & $\begin{array}{l}\text { who throws stones } \\
\text { the stone will fall on him }\end{array}$ \\
\hline
\end{tabular}

In the traditional traditions of the people to the Maluku islands, the stone is a symbol of strength and a sign of greatness in the cosmological building of the local island community. The stone symbol is a sign of strength in interpreting nature and social rules $[32, \mathrm{p} .6]$. In the oral tradition, it contains the understanding that anyone who violates any rules regarding social or religious rules will surely punish. Traditional institutions give this law in various forms, one of which is ostracizing from the country, flogged, or reprimanded. Furthermore, an essential rule is a punishment from God, the creator of the universe. Who throws stones, the stone will fall on him, which is always tell in any event that when humans turn a stone, the stone will pinch it / override it. Siapa yang melanggar janji, janji makang (membunuh) dia. In the sense that whoever lives in the land, which makes mistakes on earth, sin and threats will turn towards him. In an intrinsic sense, whoever claims to worship Allah must not break the rules. (Interview with Chairman of Saniri Batu Merah Salem Tahalua 07/13/2019).

Maluku, which is also commonly called Nusa Ina (Ibu Island) in whatever customary law we are one brother, please help, respect, and tolerance. Pasawari is always associated with religious events, and pastors are present to start praying in the church, which is attended by traditional institutions and domestic children. One area that still maintains the ceremony "Pasawari Kunci Negeri," one of them is Makariki Negeri, Amahai Seram Selatan sub-district, Maluku Province.

Pasawari is everything done by the adat apparatus concerning customs in the community. For example, when there are problems in the village, welcoming guests, the inauguration of customary kings, and congratulating a country. One of Pasawari, which is still developing, is "Pasawari Kunci Negeri. "Pasawari Kunci Negeri "is a tradition that maintained through rituals carried out by domestic children, and in the ritual or ceremony, there is an oral tradition that offers. This oral tradition is full of meaning, which contains religious moderation, which is maintained and carried out by traditional institutions, religious leaders (priests), and domestic children at the end of the year on 31 December. The heads of Soa perform this ritual before the ritual begins; there will be prayers performed by all the country's children in the church. After the pastor preached and the prayer was over, the children of the country would return to their homes to do nothing for an hour and offer prayers through oral tradition. Whoever left the house at that time, the locals believed they would get reinforcements. Moreover, this rule is obeyed by residents to be silent for a moment. That is why it is termed the Key of the Country, because all the people who reside in that place must not go out of the house and lock the door of their respective houses while telling oral tradition, when the doors of all houses are locked then this country will also be locked by traditional institutions in the four corners of the compass in the procession they will pray these verses of oral tradition by four Soa chiefs and other traditional instruments such as the Saniri (Interview on 7/14/2019 Amrusius Ami Titiahy Kelapa Soa Latu Makariki). 
After praying in the church, this "Pasawari Kunci Negeri will do baileo. Baileo architecture reflects a microcosm of the traditional universe. Separation of patasiwa/patalima can see through the way the Baileo was built and the location of the Pamali Stone. If a group belongs to the Patasiwa group, the building on a supporting post, as the Ambonese calls it, depends, and the stone place on the side facing the mountains. In contrast, the Patalima group's baileo was built on a dirt floor slightly raised to the floor with a pamali stone located on the side facing the sea. Furthermore, in Patalima villages, Baileo, and the church or mosque face each other in the village square while in the patasiwa village, the church or mosque is to the left or right of Baileo, forming a 90\% angle when viewed from the Alun-alun [26].

Traditional architecture is one of the cultural products owned by Indonesian people. The tradition to build a building is realized or not is an architectural tradition that has been carried out by ethnic groups in Indonesia since ancient times. Architecture in a tribe is always related to the beliefs held, climate, and local natural conditions and their livelihoods [28]. Baileo domestic architecture Makariki each Soa has pole position in every corner of the then legitimize status hierarchy in society. The Head of Soa consists of four Questions in the Country of Makariki, namely:

1. Soa Latu. Which consists of several clans, namely the clan Lawaheri, Maerima, Titiahy.

2. Soa Wael (big water). Which consists of several clans, namely the great Wattimena clan, and Wattimuri.

3. Soa Alang consists of two Titihala clans and Titiheru

4. Soa Wae consists of little Wattimena and Hotoru.

These four Soa Heads performed a ritual at Baileo Rima Waellekutu Makariki Siwalete Maatita. These oral traditions they say in the four directions of the wind, namely east, west, north, and south. The heads of Soa will go around the village and say an oral speech. Nevertheless, when a violation committed by the children of the country, the oral speech is turned to the place where the stone pemali under the position next to Baileo Rima Waellekutu, Makariki Siwalete Maatita.

The position of the Head of Soa was passed down from generation to generation by taking a line from the male side. So that the oral tradition that includes all the spoken verses will be passed down from generation to generation without writing, the Head of Soa will rely on this memory and pass it on to their respective descendants. The position of the Head of Soa is an extension of the head of the village, which has the task of protecting the community, regulating land boundaries, collecting taxes for each country's land. From this country's land is a common property that is shared with each clan to manage it. From the results of this land tax/tribute collected by the Head of Soa, which then in the year will be distributed to the church and mosque after the procession "Pasawari Negeri Negeri" is carried out.

This procession was also carried out in various indigenous countries throughout the region that inhabited the area that stretches from the Amahai District (South Seram) to the Tehoru District (East Seram) in tradition for generations to the present generation. With their respective religious beliefs, one example is from the Christians in the Makariki country and the Muslims in the Sepa country. Today the Head of Soa also functions as a mosque device in Islamic countries, as well as in Christian countries becoming a church device. (Interview on 7/15/2019 Amrusius Ami Titiahy Kelapa Soa Latu Makariki).

The following is the contents of the oral traditional temple verse "Pasawari Kunci Negeri."

TANAH LANGUAGE

TANAH LANGUAGE TRANSLATION 


\begin{tabular}{|c|c|}
\hline $\begin{array}{l}\text { Ami Somba Puu Lanite } \\
\text { Bumi sasorga }\end{array}$ & $\begin{array}{l}\text { We worship the God of the heavens } \\
\text { and earth that is in heaven }\end{array}$ \\
\hline $\begin{array}{l}\text { Seintalo Siwalete Maatita } \\
\text { Tabianya puu Kapitano, lee } \\
\text { Masesy ooo } \\
\text { Au Hormate pu pasakio Sanirio, lee Henapuno } \\
\text { Ami nee puu Pasakio, Upu Latu/Ina } \\
\text { Lee Saniro se intala Siwalete }\end{array}$ & $\begin{array}{l}\text { The whole country of Makariki } \\
\text { Greetings to the captains } \\
\text { Commander } \\
\text { And we respect the heads of Soa, Saniri, and Landlords } \\
\text { We respect the head of the king of a male and female } \\
\text { king } \\
\text { And Saniri is the whole country of Siwalete Maatita }\end{array}$ \\
\hline $\begin{array}{l}\text { Maa tira, Horas nee Ami Uaplae } \\
\text { Mae Nusu Mae, Mae Suru Lau } \\
\text { Iee Intalo nee, Mae Saka saka meke } \\
\text { Nee se Intalo Karena tahun se ine } \\
\text { lee Pelasinya Le Hakae }\end{array}$ & $\begin{array}{l}\text { This time we ask kalua } \\
\text { Let us descend into the sea and enter this country } \\
\text { Let us take care of this country because of this country } \\
\text { Already at the end of the year } \\
\text { And this year has passed }\end{array}$ \\
\hline $\begin{array}{l}\text { Ku Mau Lee poko saparang ke } \\
\text { Ami harapa Ampune Lee Puu } \\
\text { Mee Puu Suru Lau ee } \\
\text { Berkati Lee Merindo Lee Asiolo } \\
\text { Mae Saka Saka Meke Anai ee Lee } \\
\text { Honto Poina Menuntut Ilmu } \\
\text { Lee Palahi Anai ee berkat } \\
\text { Do Au Hormate Ponu Ponu }\end{array}$ & $\begin{array}{l}\text { We ask for forgiveness } \\
\text { We hope for your forgiveness } \\
\text { Let us go down to the sea } \\
\text { Give blessings to the garden and the sea } \\
\text { Let us take care of these children } \\
\text { Who is studying outside? Give these children a fortune } \\
\text { thank you very much }\end{array}$ \\
\hline $\begin{array}{l}\text { Tabaianye Laen Siwa lai Rima } \\
\text { Oo Au Hormate } \\
\text { Pono Pono }\end{array}$ & $\begin{array}{l}\text { We respect patasiwa and patalima } \\
\text { Give respect } \\
\text { With pleasure }\end{array}$ \\
\hline
\end{tabular}

(Interview on 7/15/2019 Amrusius Ami Titiahy Kelapa Soa Latu Makariki).

Ami Somba Puu Lanite Earth sasorga, We worship the Lord God of heaven and earth in heaven. In the first stanza, Upu lanite they mean is God in the sky. Country kids believe and worship the God who made heaven and on earth is in heaven. They believe Upu Lanite is God, who has protected them from giving a fortune. The fortune of God is not only for the Gospel people but also for other people. Guarding the land protected by God is also for other people. The results of Earth in the garden/forest and the ocean is a gift from God to all humankind. The country they inhabit must protect from various mistakes. The children of the land are expected not to make mistakes with other humans. This teaching finds in the New Testament book of Love, 1 Corinthians 13, verses 1-13.

Even though I can speak in all human language and the language of angels, but if I have no love, I am the same as the reverberating gongs and the jingling cymbals.

Even though I have the gift of prophecy and I know all the secrets and have all the knowledge, and even though I have perfect faith to move mountains, if I do not have love, I am 
completely useless. 13:2.

And even though I share everything that exists with me, even surrender my body to be burned, but if I do not have love, there is no benefit at all. 13: 3 .

Love is patient; love is generous; he is not jealous. He does not boast and is not arrogant. 13:4.

He does not do anything rude and does not seek self-interest. He is not angry and does not save the mistakes of others.13: 5 .

He is not rejoicing because of injustice, but because of the truth. 13: 6 .

He covers everything, believes everything, expects everything, endures everything. 13:

7.

Love never ends; prophecy will end; tongues will cease; knowledge will disappear. 13:

8.

Because knowledge is incomplete, and our prophecies are imperfect. 13: 9.

Nevertheless, if the perfect arrives, the imperfect will disappear.13: 10 .

When I was a child, I spoke like a child, I felt like a child, I thought like a child. Now that I have matured, I left that childish nature. 13:11

Because now we see in the mirror a vague picture, but later we will see face to face. Now I only know imperfectly, but later I will know, as I know myself.13: 12.

Thus these three things remain, namely faith, hope, and love, and the greatest of them is love. 13: 1. www.sabda. web.org

Respect for all customary instruments and legislative instruments they pray for. This is in line with the teachings of the Book (Perjanjian Baru) Matuis 22 verse 21. www.sabda. web.org

Upu Lanite manifests from the Lord Jesus, to come down to earth, giving them a fortune in the forest and the ocean. For all residents of the country, for all humanity. This is stated in the New Testament of Love, 1 Corinthians 13, verses 1-13. The Lord Jesus grew fortune on earth and in the sea. Furthermore, it is intended for all human life on earth. (Interview of Mrs. Non Doden Unpatti 07/21/2019).

In the last fifth stanza, which contains Tabaianye Laen Siwa lai Rima which means We respect Patasiwa and Patalima. This is in accordance with the custom that their native ancestors must still be given the respect that they consider to be landlords who have mystical relations with the land (island) so that their generation is not affected by disaster [33, p. 451]. There is a tribute given to the two largest groups in Maluku society. Confessions of different religions are seen and recognized, where patasiwa are identical with Christian community groups, and patalima are identical Muslim communities.

Patasiwa means group pata, and Shiva means nine while patalima groups five. In the Seram community, there are two large community groups, one called patasiwa and patalima. Once upon a time, they were one because of the great war that was caused by the struggle for the hegemony of power. The economy was then solved; they became pata shiva and pata lima. This group partially ran to Ambon Island, while some ran to Seram, Lease Haruku Saparua, and Hitu islands. Even though they are in remote areas, they still form groups so that in the villages, there are still characteristics that distinguish between patasiwa and patalima. For example, the patenting group had all nine dowries as well as the dowry pats in multiples of five. Plates, spoons, cups, and others follow a multiple of five and a multiple of nine. Likewise, when they dance cakalele, the Shiva group will always say Shiva, Shiva, Shiva. The chicken feathers they tuck in their limbs also amount to their respective groups. Usually, in patasiwa groups, it usually refers to Christians, while the patalima will refer to Muslim groups. Nevertheless, that does not mean religious segregation, when the Dutch came they were separated, they were then told by 
the invaders to group together. But mixing still existed at that time, and to this day even though they have segregated settlements, the identity of patasiwa and patatima remain in their circles. (Wawancara Ibu Florence 13/7/2019).

Ancestors of the Children of the Moluccas, in addition to building a new social construction as a society that they created for their internal interests so as to form a country soa with all the values in it, they also carry out social interaction with the community in other countries in the form of pela, gandong duan lolat, maren, larvulngabal, kalwedo and so on [1]. The social patterns that they built bridged them to interact with each other beyond the borders of the island, religion, and culture as an identity to recognize each other's differences but wisely understand those differences and love each other peace among the children of the land.

\section{The Function of Oral Traditions in Building a Climate of Religious Moderation}

A peaceful life between religious people is a condition of harmony that has lived in the daily life of the community that occurs naturally [34, p. 41]. The function of the Oral tradition in building a religious climate of moderation in which one of the functions is the creation of harmony and mutual respect for fellow religious communities. The oral tradition was still spoken and spoken, but now, it is only spoken at traditional ceremonies, expressions, and rhymes when adat is performed. Furthermore, to provide a function in building a religious climate, customary institutions and related government must be involved.

Basic principles of "Pasawari" All total humanity that applies on earth is addressed and offered to God, the creator of the universe. In the ritual/ritual, "Pasawari" is always done at home (Baileo). Adat and religion are always juxtaposed, the heads of Soa praise and worship, and ask for help from God in total life in the customary land. Samawi religions teach to worship God who is in the sky, and this means that all Samawi religions have in common the existence of the one power that created nature and all of its contents.

According to Ms. Nun, "I am a Christian, but I also study the Koran, the way we religion depends on the point of view of our understanding to see the religion. All religious teachings contain teachings of peace, such as the teachings of love in the Gospels and the teachings of Rahmatan Lil Alamin in the Qur'an ". (Interview of Unpati Lecturer Unpati on July 21, 2019).

Before the riots hit two Muslim and Christian countries, so the Soas will pay a visit to the two places of worship after the "Pasawari Negeri Negeri" is carried out by bringing tribute derived from the contribution of Muslim and Christian communities who are in the customary guidance inhabiting the Kampung. A tribute also comes from natural resources owned by the land of petuanan. The value of brotherhood in their religious differences is one of them in giving tribute to two different faith communities.

The tribute derives from agricultural products in the sea and in the forest guarded by customary police called Kewang appointed from each soa. The position of Kewang in maintaining the balance of nature is great. Forest products should not be taken arbitrarily, as deforestation is strictly prohibited, even in the ocean, fishers must take marine products considering fish habitats that must not use explosives, the Kewang must license gravel and sand dredging. This natural product is what they set aside for the tribute collected for one year. (Oma Gres interview July 17, 2019)

Currently, they are aware and trying to get up to organize the future after being hit by a humanitarian conflict that takes casualties and property. Their strong cultural roots were knitted back through the realization that some of the traditions planted by their ancestors were an 
effective way of building peace in the Moluccas. So when the conflict passed, some Muslims began to enter the Christian area doing economic activities such as peddling merchandise and vice versa. In crowded centers such as markets, offices, educational institutions will look harmoniously intertwined naturally.

At present, the livelihoods of Makariki residents are farmers, and fishers are some employees. The results of their efforts set aside for tribute. They believe that the tribute is a fortune that must earmark for the entire church or mosque, and after the riots, in Maluku, the Muslim and Christian settlements did not mix anymore, but even so, the 'Pasawari Key Negeri' event was held one of them in the land of Makariki. Makariki residents always visit the Islamic land, and they will entertain and warmly welcome the guests who come. One time the Muslim Ruta State residents built a mosque, then the Head of Soa, who heard this news, gathered the men to beat sago, and the results were taken to the Ruta Country to use as food for the mosque construction workers. Harmony is knitted by traditional institutions, and they hope government officials pay more attention to these traditional institutions.

The socio-cultural life of the Moluccans is known for the relationship between religious people who are very harmonious with a high level of tolerance among people, as universal energy of kinship/brotherhood that may not find in other regions in Indonesia. The reason to build a mosque in a country, there must be a community of some or some other Christian country that must be responsible for completing some parts of the mosque. Conversely, to build a church building, a generation of generations has been done for a long time. Children of the Moluccas state that the building of worship is not only the property of each adherent (Islam / Christian) but belongs together to look after it. The gandong culture, pela, and other fraternal, cultural institutions put them in that obligation/responsibility and received happily. The situation was different when entering the second day of the 1999 Maluku conflict and lasted for some time [1]. At that time, the Moluccas cried; they lost their property, and lives were lost. Brothers and sisters divorce each other, harmony instilled by the ancestors uprooted from its roots. Nevertheless, when the trees die and wither, several other trees grow to shade the trunks of the dead tree to grow new shoots that are more soothing and shade so that they can provide shade for the people shelter underneath.

One area in Ambon city that still maintains togetherness even though the surrounding area has been devastated is consumed by incitement in the midst of conflict, that is, the area in Ambon city precisely in the Muslim Muslim Wayame area has never separate because of the strength of the church and the power of Islamic figures guarding their villages when riots occur. Until now, the village is still safe from the expression of traditional leaders, community leaders, the government of the country/village said to its citizens 'bahwa seng boleh ada dari pihak Islam maupun Kristen keluar kampung dan dari pihak luar baik Islam maupun Kristen tidak boleh datang memasuki wilayah mereka. They tried to isolate themselves, so provocateurs from outside would not influence them, so the village was safe until now. The community highly obeyed the religious parties on both sides. Every night they guard the village, but outsiders are prohibited from entering because the residents will be contaminated and affected whether he is Muslim or Christian or even relatives from the outside. This village was tried to be isolated when the riots hit Ambon city. The same understanding that this complex must close from the influence of outsiders. Furthermore, now this village is better. Those who guard the church are Muslims, who guard Christian mosques, so they look after each other's neighbors' worship places in this village. That phrase constantly remembers and used as an oral tradition in society 'Kalau beta, so kasi kepercayaan ale jaga beta pung gereja, begitupun beta jaga ale beta pung Masjid. (Interview of S Pasyiama and Ongen on 7/20/2019). 
This phrase is very meaningful togetherness, and understanding of the two places of worship that jointly own mutual feelings have imprinted on their hearts, even though the same function, functioning church for Christian worship and mosques for Muslims, pray. The success in building social solidarity was born from their obedience when the oral tradition was imprinted and indeed applied; in fact, individual and collective awareness was built to establish peace between them in the midst of the conflict that was happening at that time. Furthermore, this settlement until now, there is no segregation; they blend in understanding differences in terms of religion, social, and culture.

\section{Policy Development and Implementation Strategy}

After the enactment of Law: 5 of 1979 then Law number 22 of 1999 amended again by Law number: 32 of 2004, the structure of the government of the country also adjust to the provisions contained in the law, and all government activities are center in a state office. Furthermore, all budget designs give customary rights and obligations, one of which is, beginning in 2019, the customary institutions sit together with the state government to propose the Amahai Subdistrict Makariki Budget Budget Draft for the 2019 fiscal year. Village funds have been prepared, and one of them intends for higher-ups under the auspices of traditional institutions. The Draft State Budget of Makariki in Amahai Sub-district in 2019 has prepared. It contains the Intensive Provision of non-formal Religious Institutions. The intensive give to the priests, Catholic priests, pastors of the congregation of God, Intensive pastors, and Intensive Pentecostal pastors. IDR 300,000 / month. Likewise, the Intensive payment of adat institutions, the Soa heads, and landlords received an intensive Rp. $30000 /$ month. Likewise, the maintenance budget for Baileo and the budget for adat institutions' events include in the draft.

Policy Development and Implementation Strategy

After the enactment of Law: 5 of 1979 then Law number 22 of 1999 amended again by Law number: 32 of 2004, the structure of the government of the country is also adjusting to the provisions contained in the law, and all government activities center in a state office. And any budget plan. With the existence of a draft national cost, what must be done by the Ministry of Religion, synergizing with the state government in the villages, and the traditional institutions in Maluku, religion and mythical figures, the government is empowered. Through the Christian Community Guidance of Christian religious counselors and Islamic instructors in KUA, efforts are made to touch the grassroots strategy. Arranging a strategic position, because it is the instructors who most directly interact with customary institutions, faith by building intensive communication and taking action in various collaborative events.

Religious figures, educator figures, and traditional leaders use as adat-based peace agents. They have a respected position in indigenous communities. Even though they do not have the authority of a country/village government, the recognition of indigenous peoples of their status gives them strong social legitimacy that places them as "influential" people and role models in their environment. They are people who want to work sincerely, sincerely, and honestly to work on peace in the indigenous people of Orang Basudara. Customary-based peace agents are traditional leaders and indigenous people who have traditional charisma, as well as knowledge of the customs of the Basudara people

customary institutions give rights and obligations, one of which, early in 2019, adat institutions sat down with the state government to propose a draft Budget for the Makariki State Budget of Amahai District in the 2019 fiscal year. Village funds had been prepared, and one of them intended for senior officials under the adat institution. The Draft State Budget of Makariki in Amahai Sub-district in 2019 has prepared. It contains the Intensive Provision of non-formal Religious Institutions. The intensive give to the priests, Catholic priests, pastors of the 
congregation of God, Intensive pastors, and Intensive Pentecostal pastors. IDR 300,000 / month. Likewise, the Intensive payment of adat institutions, the Soa heads, and landlords received an intensive Rp. 30000 / month. Likewise, the maintenance budget for Baileo and the budget for adat institutions' events include in the draft. [25].

In the village of priests, priests, teachers, and traditional leaders, three stone stoves must be involved. When priests talk, priests, traditional leaders speak, people obediently listen. The function of oral tradition, which is culturally remembered, by the stakeholders of the oral tradition culture, is encouraged again. This oral tradition is proven to be able to reduce conflict and is full of the meaning of tolerance and peace, which is framed in the understanding of religion on the Christian side with the teachings of Love and the Muslim Rahmatan Lil Alamin.

Since ancient times pastors have been positioned as "apparatus" of local priests, namely people of the earth who have a closeness to God's hands. On the other hand, administratively, the priest, is positioned parallel to the local kings in the Ambon islands. The priest also acts as a school teacher; the influence of the church also position parallel to the king's father [31].

Policies for curriculum in the field of religious education must be recorded and used as a resource for inventorying these oral traditions. If the current generation can only understand when their parents speak this language, but cannot speak the results, this oral speech will disappear. Customary institutions and teachers, priests, pastors are used as resource persons to teach the next generation by giving an injection of funds. Priests, teacher priests, and traditional leaders were presented and given roles to preserve this oral speech. After this make, it proposes local content in the field of Religious Education. Each village has a local content curriculum to be taught in schools ranging from elementary/Ibtidaiyah, junior high/Tsanawiyah, to high school/Madrasah Aliyah.

Pasawari how it is spoken and encouraged again, it is possible to do recordings by traditional elders to inventory the oral tradition. Because only the eyes of the oral speech are alive, these speakers must embrace. Because every Head of Soa automatically, the office is hereditary, and only my son will inherit this question. So all knowledge regarding language and pasawari only passed on through oral speech alone is not recorded and not written, then all of it disappears.

The recording does before parents who understand and are proficient in telling oral traditions that the smell of religion records. Then it is contested in schools so that the students' enthusiasm to learn it. So the content of the local curriculum containing religious lessons is the regional language of oral traditions containing religious moderation taught in schools. If it is covered by a Regional Regulation (Perda), by approaching adat, and the regional kings make a program of preservation of oral traditions in religious understanding. Maluku cultural congress is often carried out and must have implications for the inculcation of cultural values instilled through the oral tradition of religious understanding. If necessary, all buildings in Maluku have the characteristics of the Maluku region. Government buildings must have the characteristics of the local treasury, and there is a motto of expressions containing oral traditions that contain the power of religious moderation that has the value of harmony that invites togetherness. When these expressions become writings attached to the center of the crowd in the corner of the city and the village, it will build the imagination, which sticks in mind with the aim of the trauma of the Maluku conflict in 1999-2004 slowly erased memory.

Husni Putuhena, a Muslim scholar, revealed, "Why do we only know languages from abroad such as English while our regional languages disappear. In the Maluku region, there are only villages in Islamic villages that still use regional languages, but in Christian areas, it is almost extinct, but there are still several village villages in areas such as the Haruku, Oma, 
Hulaliu and Seram islands where Christian villages still speak this language. Nevertheless, when in Muslim areas in the Tulehu, Liang, and Hitu regions, you will see that they still speak their native language. Because in their house, they still use it as the language of everyday conversation " (Interview of Husni Putuhena 7/20/2019).

The emergence of population registration in the early twentieth century led Ambonese people to become urbanites who had a registered status. Ambonese have the right to send their children to Dutch-language educational institutions. The emergence of new schools, especially in Christian children's schools, is prohibited from using local languages - instructions for using Malay and Dutch. The modernity of Education is rapidly awakening the emergence of an awareness of status. Getting Education means being entitled to label power and attributes as "Black Dutch" (Black Duthcmen). Before 1930, education in the Islamic community was considered not modern. The education system still does not separate the curriculum material "worldly" with a curriculum based on religion. Some religious schools are taught by Javanese and Gujarati students who come far off the coast, such as Tulehu and Pelauw, an inland region on the eastern tip of Ambon Island. The support of educational facilities is still very minimal. Unlike educated Christians who work in government and become priests, Muslims who leave the city of Ambon instead work in the fields of shipping, commerce, and becoming pilgrims to the holy land of Mecca [31].

Children of the country who convert to Christianity will not only get more privilege than Chinese, Javanese, Makassarese, and Butonese migrants, but also they will be safe from attacks by other ethnic groups who do not embrace Christianity. Being a Christian in the colonial era was to be modern, educated, civilized, and to have a more powerful status at the government level. In 1625-1630 a Calvinist Protestant Priest, St. Paul, had given a lecture in front of his congregation using Malay [31]

The marginalization of the Islamic community throughout the colonial period made this religion more static in maintaining the traditional values of Ambon. The Netherlands did not introduce the Islamic education system, which continued in the modern work system [31]. Not touching them with modern education has implications for local languages that still maintain in the Muslim community. Even some of them do not want to go to a Dutch school.

According to Mr. Nur Tanaiwella, he is one of the cultural figures in Ambon city who had attended a Dutch school and revealed that when the Dutch during the colonial period provided facilities for Moluccan children to experience the world of education we used Malay as the language of instruction. The Dutch government invites domestic children to go to school, and the Dutch teach Malay. While from the Islamic side, some parents forbid their children to go to school because they do not want to come into contact with the invaders. Nevertheless, among Christian children, most of them enter the world of education so that the Malay language acquired in school becomes their language also in their daily life outside of school so that gradually, the regional languages did not use anymore. In this day and age, some of them are unable to speak their local language phenomena of local languages no longer live mostly in Christian villages. This is also supported by the mission of the evangelists to spread their teachings using Malay.

Furthermore, slowly but surely, the sermon in the church uses Malay. Even the children of the country who said it had replaced the local language with Malay. The country boy who became a priest preached the teachings of the Bible in Malay. The speech culture spoken by parents lost in some Christian villages due to the dominance of the Malay language taught by the Colonials. With the politics of de pi de impera, colonial divide the Moluccans by trying to erode the language of their area so that they are not able to speak and communicate with their fellow Muslims. 
Nevertheless, on the island of Ambon, only in Salahutu, Tulehu, Liang, Hitu, Zeith, Mamala, and Morela still use the mother tongue. What their children worry about is understanding but can no longer say it. Furthermore, they can not dialogue anymore.

Understanding cultural values is important to be instilled in each of these generations. Language is our identity, if the language is gone, we are not Ambonese anymore. Speech culture like this is losing interest in culture. (Interview with Nur Tanaiwella on July 21, 2019).Beberapa daerah pelosok yang masih tetap mempertahankan bahasa daerah, apa yang diungkap seorang tokoh pendidik Bapak Yuswarlekka, Saya berasal dari Maluku Barat Daya Ke pulauan Tanimbar. Karena di daerah tersebut penggunaan bahasa daerah masih dipupuk dan menjadi percakapan dikeseharian maka digalakkan Kitab Injil diterjemahkan ke dalam bahasa Daerah Tanimbar, sehingga diupayakan para pendeta berkhutbah menggunakan bahasa daerah Tanimbar ( Wawancara Bapak Yuswarlekka 22/7/2019).

According to Ms. Florence revealed "Di Maluku lembaga adat tidak ada yang mengatur bahasa, pelestarian budaya dan bahasa tidak ada sama sekali bahkan situs budaya banyak yang dilupakan. Namun demikian dalam sebuah acara ritual masih dituturkan ketika acara adat berlangsung maka pemuka-pemuka adat berkumpul menuturkan bahasa daerah dan ungkapan unkapan mereka sangat berbau moral selaras dengan agama dan persatuan. "

Iha Kulur is an area that still speaks their local language. Tulehu Village, in Pelau Rohomoni, Kabau, Amarima, the language of this region is still well preserved. On the Christian side, their local languages make discoveries of the terms themselves according to their wishes. The oral tradition spoken by muzzled and died automatically almost all regional languages in the Christian area became extinct and no longer became a mother tongue. In one Christian village, only a handful was able to speak their mother tongue.

In 2008 a regional language seminar was held on the island of Seram, the result was that only 30 to 40 Christians in Seram Island were still able to use their mother tongue, but on the Muslim side almost entirely they used their mother tongue. Because most of them were enemies at the time of occupation, so the local population was not touched by the influence of the invaders who tried to replace the local language with their language and Malay because spoken speech could unite rural communities while the colonizers were trying to suppress residents to speak more according to their language and Malay. The reason the colonizers at that time if they were still speaking in their language then it would be difficult to separate one relative from another. So that the residents who were touched by Dutch education and entered into the religion they brought tried to embrace the population by getting used to speaking in Malay and following the language of the colonizers. So that what developed in Maluku, especially in the Christian area at that time until now, the thickness of the invaders' language is so typical, for example, from the Christians, when they say thank you, they will say dangke, destroying the mother tongue in Maluku is what the people do invaders. In Maluku, unlike in other regions, every region has a comprehensive language that occupies the Bugis region, so at the same time, there is a language that is maintained and spoken if in Maluku each country has a different language than the others. By using Malay, they use their language to talk with each other. So that the Dutch crushed the original language, and there was political pressure from the colonizer. Nevertheless, on the part of Islam even at this time gradually, but surely there are already symptoms in urban areas, Millennial children are not able to speak with their local language. By using Malay as an intermediary language. This phenomenon occurred in the 18th century. In the Christian area and the Islamic region in the 1970s, they communicated in local languages. In the 1980 s, they rarely used local languages; one of the factors was that children left the village to go to school. Just keep them away from their mother tongue. As a result, there was a shift in the value of verbal expressions that contained moral precepts, the unity that smelled peculiar to 
religion lost in their memories. What they brought home from the palace smelled of modernity. (Interview of Mrs. Florence, retired head of the Cultural Heritage Center \& Head of the Maluku Province Tourism Office interview at her home July 13, 2019).

\section{Conclusion}

Pasawari was born from their ancestors, who tried to dialogue through oral tradition with ancestors (ancestors), in the language of the land they understood. The older people's habits when expressing their problems, about the security of the country, guarding the gardens, guarding the oceans and problems of life of the country. With the hope that they will always be protected in danger and given a blessing (fortune) and avoided all hostility from fellow humans. Love of respect for nature, plants, fellow humans is teaching that contains in this oral tradition. Whatever social differences tribes and religions must always maintain the peace of the country. Excavation of the values of the past that still has significance when revived. As a driver of peace for humankind. Custom has long been proven capable of maintaining peace for centuries.

Oral tradition in developing a religious climate of moderation that developed in Maluku still speak and speak, but now, it is speaking at traditional events, expressions, rhymes only when customary events are carried out. Furthermore, to provide a function in building a religious climate, customary institutions and related government must be involved. This oral tradition can be designed as a supplement to build a climate of peace on the Moluccas after the 1999 Maluku conflict and lasted for some time. At that time, the Moluccas cried; they lost their property, and lives were lost. Brothers and sisters divorce each other, harmony instilled by the ancestors as uprooted from the roots.

Nevertheless, when the trees die and wither, several other trees grow to shade the trunks of the dead tree until new shoots grow, which are more soothing and shade so that they can provide shade for the people under the shade. The Maluku generation is increasingly aware that their ancestors taught peace, brotherhood through adat compared to religion, one of which was "Pasawari Kunci Negeri Negeri."

The Oral Tradition Development Strategy can be designed on a village/country scale and then on a city scale, considering that priests, priests, teachers, and traditional leaders are the three stone stoves that must be involved. When the priest speaks, the priest of the adat leader speaks with exceptional adherence to the community's hearing. The function of oral tradition, which is culturally remembered, by the stakeholders of the oral tradition culture, is encouraged again. This oral tradition is proven to be able to reduce conflict and is full of the meaning of tolerance and peace, which is framed in the understanding of religion on the Christian side with the teachings of Love and the Muslim Rahmatan Lil Alamin. The regional languages / languages of the Land that use in every traditional event have started to become extinct in the community. So the traditional elders must be directed to provide courses through the Sunday school of the church and the Muslims, which are covered by a Regional Regulation (Perda). To build a collective memory among state children in Maluku, Country/village-based cultural resilience as conservation builds a culture of religious moderation.

\section{REFERENCES}

ADDIN Mendeley Bibliography CSL_BIBLIOGRAPHY [1] Semuel Waileruny, Membongkar Konspirasi di Balik Konflik Maluku, 1st ed. Jakarta: Yayasan Pustaka Obor Indonesia, 2011. 
[2] Y. Kawangung, "Religious moderation discourse in plurality of social harmony in Indonesia," Int. J. Soc. Sci. Humanit., 2019.

[3] M. Beragama, B. Minoritas, M. Etnis, T. Di, and K. Makassar, "Moderasi Beragama bagi Minoritas Muslim Etnis Tionghoa di Kota Makassar," 2019.

[4] A. Saefudin and A. F. Al Fatihah, "Islamic Moderation Through Education Characters of Aswaja An-Nahdliyyah," Nazhruna J. Pendidik. Islam, 2020.

[5] N. F. Abdul Rahman and K. Mohd Khambali, "Religious Tolerance in Malaysia: Problems and Challenges," Int. J. Islam. Thought, 2013.

[6] K. A. Shinde, "Religious tourism and religious tolerance: Insights from pilgrimage sites in India," Tour. Rev., 2015.

[7] J. S. Wrench, M. W. Corrigan, J. C. McCroskey, and N. M. Punyanunt-Carter, "Religious Fundamentalism and Intercultural Communication: The Relationships Among Ethnocentrism, Intercultural Communication Apprehension, Religious Fundamentalism, Homonegativity, and Tolerance for Religious Disagreements," J. Intercult. Commun. Res., 2006.

[8] R. Ahmad, "Penguatan Moderasi Beragama," Kompas, Jakarta, 2019.

[9] J. N. Hook, J. E. Farrell, K. A. Johnson, D. R. Van Tongeren, D. E. Davis, and J. D. Aten, "Intellectual humility and religious tolerance," J. Posit. Psychol., 2017.

[10] P. A. Djupe and B. R. Calfano, "Religious Value Priming, Threat, and Political Tolerance," Polit. Res. Q., 2013.

[11] F. J. Potgieter, J. L. van der Walt, and C. C. Wolhuter, "Towards understanding (religious) (in)tolerance in education," HTS Teol. Stud. / Theol. Stud., 2014.

[12] I. M. \& K. Abdullah, "Pendidik Pembina Negara Bangsa," in Prosiding Seminar Kebangsaan Majlis Dekan Pendidikan Universiti Awam 2017, 2017.

[13] Y. Friedmann, Tolerance and coercion in Islam: Interfaith relations in the Muslim tradition. 2003.

[14] G. Levy and R. Razin, "Religious beliefs, religious participation, and cooperation," Am. Econ. J. Microeconomics, 2012.

[15] X. Zhu et al., "Together Means More Happiness: Relationship Status Moderates the Association between Brain Structure and Life Satisfaction," Neuroscience, 2018.

[16] T. Islam and A. Khatun, “Islamic Moderation' in Perspectives: A Comparison Between Oriental and Occidental Scholarships," Int. J. Nusant. Islam, 2015.

[17] M. Farid, "Dialog dan Toleransi Beragama di Kota Ambon: Perspektif Bekas Pejuang Muslim Ambon," Int. J. Islam. Thought, 2016.

[18] M. Amri, R. Mosiba, and S. Z. Bin-Tahir, "Interreligious Tolerance in the Perception of Maluku Muslim Society," J. Adab., 2020.

[19] M. Sahetapy, "Potensi Kearifan Lokal Sasi Biodiversity Laut Di Maluku Dalam Penguatan Pembelajaran Sains," Pros. Semin. Nas. Pendidik. Biol., 2018.

[20] O. Montana, R. Loisa, and L. S. S. Utami, "Masyarakat dan Kearifan Budaya Lokal (Bentuk Pela Masyarakat di Negeri Batu Merah Kota Ambon Pasca Rekonsiliasi)," Koneksi, 2019.

[21] H. Bakri, "Resolusi Konflik melalui Pendekatan Kearifan Lokal Pela Gandong di Kota Ambon," Polit. J. Magister Ilmu Polit. Univ. Hasanuddin, 2015.

[22] H. Tualeka Zn, "Kearifan Lokal Pela-Gandong Di Lumbung Konflik," El-Harakah (Terakreditasi), 2012.

[23] U. Thalib, "Kajian Pembangunan Berbasis Komunitas Studi Kasus Di Daerah Maluku," J. Penelit. Seri Pnb. Sej. Budaya, vol. 6, no. 4, 2012.

[24] A. Muslim, "Artikulasi Religi Sajak-Sajak Basudara di Maluku," Alqalam J. Penelit. Agama dan Sos. Budaya, vol. 19, no. 02, pp. 221-230, 2013.

[25] A. dkk. Watloly, Perdamaian Berbasis Adat Orang Basudara., 3rd ed. Dawrah Istimewa Yogyakarta: PT Kansius, 2018.

[26] D. Bartels, Di Bawah Naungan Nunusaku Muslim-Kristen Hidup Berdampingan di Maluku Tengah. Jilid 1 Kebudayaan, 1st ed. Jakarta: PT Gramedia, Jakarta, 2017.

[27] A. Muslim, "Tradisi Ale Rasa Beta Rasa Sebagai Perawat Kerukunan Umat Beragama di Indonesia Timur," J. Stud. Islam Progr. Pascasarj. IAIN Ambon, vol. 8, no. 2, 2016. 
[28] J. . Pattipeilohy, “Arsitektur Tradisional Tidore Kepulauan,” J. Penelit. Seri Pnb. Sej. Budaya, vol. 6 , no. 4,2012 .

[29] B. A. Saebani, Sosiologi Agama, 1st ed. Bandung: PT Refika Aditama, 2007.

[30] Y. Z. Rumahuru, Islam Syariah dan Islam Adat (Kontruksi Identitas Keagamaan dan Perubahan Sosial di Kalangan Komunitas Muslim Hatuhaha di Negeri Pelauw. Jakarta: Kementerian Agama RI, 2012.

[31] H. A. Kadir, Bergaya Di Kota Konflik/mencari akar Konflik Ambon Melalui Gaya Hidup Anak Muda. Jakarta: Pustaka Pelajar, 2009.

[32] A. Watloly, "Peran Kritis Kebudayaan Pulau-Pulau Kecil Dan Perbatasan Dalam Membangun Kebudayaan Indonesia,” J. Penelit. Seri Pnb. Sej. Budaya, vol. 6, no. 4, 2012.

[33] D. Bartels, Di Bawah Naungan Gunung Nunusaku Muslim-Kristen Hidup Berdampingan di Maluku Tengah Jilid 11 Sejarah, 1st ed. Jakarta: Kepustakaan Populer Gramedia, 2017.

[34] A. M. Djafar, (In) Toleransi-Memahami Kebencian \& Kekerasan Atas Nama Agama, 1st ed. Jakarta: PT Elex Media Komputindo, 2018. 